\title{
The Causes and Risk-Taking on the Change of CEO
}

\section{Equity-Based Compensation Structure}

\author{
Yin-Hua Yeh (Corresponding author) \\ Graduate Institute of Finance, National Chiao Tung University \\ 1001 Ta-Hsueh Rd., Hsinchu City, Taiwan 30010 \\ Tel: 886-3513-1294Ｅmail: yhyeh@ nctu.edu.tw \\ Zih-Heng Lai \\ Graduate Institute of Finance, National Chiao Tung University
}

Received: July 8, 2014 Accepted: July 25, 2014

doi:10.5296/ber.v4i2.6105 URL: http://dx.doi.org/10.5296/ber.v4i2.6105

\begin{abstract}
This paper explores to find out the determinants of the change of CEO equity-based compensation structure. We use the US nonfinancial listed companies as sample and find that when the change of stock return and size increase positively, the percentage of stock compensation and the stock-minus-option compensation relative to last year increase. Moreover, when the change of CEO duality increases positively, the percentage of stock-compensation and the percentage of stock-minus-option compensation relative to last year decrease. The empirical results represent that when firms perform better, sizes are bigger, and when there is a supervision mechanism of CEOs, stock compensation relative to last year will rise. Furthermore, the change of entrenchment index is positively correlated with equity-based compensation relative to last year. We also investigate the relation between equity-based compensation and risk-taking. Option compensation will increase firms' stock return risk, but stock compensation will decrease firms' stock return risk. Although there is no obvious conclusion that whether stocks or options are better, this study shows that stock compensation dominates option compensation in the view of risk-taking. We recommend that executive equity-based compensation should mostly consist of restricted stock.
\end{abstract}

Keywords: Stock Option, Compensation, Risk-taking 


\section{Introduction}

Stock compensation and option compensation have been two important components in executive equity-based compensation in the US S\&P 1500 firms. In 2012, the grant-date fair value of stock compensation accounted for 32.2\% of total pay in S\&P 1500 Chief Executive Officers (CEOs) and the grant-date fair value of option compensation was $15.2 \%$. Hayes et al. (2012) show that all firms dramatically reduce their usage of stock options after the adoption of FAS 123R. It is necessary to further investigate the determinants of the change of CEO equity-based compensation structure (including stock and option compensation) and study the relation between CEO equity-based compensation and firm risk-taking behavior after the adoption of FAS 123R.

The objectives of paying CEOs with equity-based compensation (including stocks and options) are to motivate its CEOs and other executives to make their companies better, because this kind of compensation could provide a direct link between companies' performance and executives' wealth. For example, shareholders try to tie manager's pay to firm performance to provide incentives for the manager to take actions that increase firm value. Besides, equity-based compensation also attracts highly skilled executives to join their companies, because these people will select firms paying more performance-based compensation rather than firms paying fixed salary only. Goergen and Renneboog (2011) also stated that stock options induce managerial risk taking, and may also increase managers' incentives to exert effort.

Despite the popularity of equity-based compensation, there are several drawbacks of option compensation. First, Billet et al. (2010) state that options incentivize managers to engage in riskier but inefficient projects to increase the stock price, leading to an increase in the option value. Also, they confirmed this negative effect is amplified when managerial power is high and shareholder rights are weak. Second, Goergen and Renneboog (2011) show that executive options have a dilution effect for the other shareholders as their exercise leads to an increase in the shares outstanding and hence a reduction in the stock price. This dilution effect further reduces the incentives of the other shareholders to monitor the management.

There is considerable controversy about stock or option compensation in the past researches. We could divide past researches into three categories: option compensation is better, stock compensation is better, and whether stock or option compensation is better depends on different conditions. For the first category, for example, Lambert and Larcker (2004) show that restricted stock is generally not the optimal contract form, and that option-based contracts with positive exercise prices have both efficiency and incentive advantages. For the second category, for example, Hall and Murphy (2002) show that restricted stock dominates options by analyzing the cost, value and pay/performance sensitivity of non-tradable options held by undiversified, risk-averse executives. For the third category, for example, Kadan and Swinkels (2008) show that stocks can dominate options as a means of motivation only if non-viability risk is substantial, as in financially distressed firms or start-ups. Options dominate stocks for other firms. Further discussion of these literatures will be presents in Section 2.

Due to the CEO equity-based compensation structure has changed, this paper examines the determinants of the change of CEO equity-based compensation structure. Empirical results 
show that, when firms perform better (cumulative stock returns are higher), sizes are bigger (the natural $\log$ of assets or market value of firms is bigger), and when there is a supervision mechanism of CEOs (the CEO are not the chairman of the directors), stock compensation this year relative to last year will rise and the stock-minus-option compensation this year relative to last year will rise, too.

As noted in past paragraphs, on CEO equity-based compensation schemes, the choice between stock compensation and option compensation is still ambiguous. In this research, we explore to determine whether stocks or options are better compensation instruments in the view of risk-taking. Goergen and Renneboog (2011) show that options incentivize managers to engage in riskier but inefficient projects to increase the stock price, leading to an increase in the option value. Therefore, does option compensation lead to higher risk? Moreover, does stock compensation lead to lower risk, equal risk, or still lead to higher risk just like options? These are important questions that have not been fully addressed in the literature.

On the basis of our analysis, option compensation, indeed, increase stock return risk and decrease return/risk ratio. However, stock compensation decrease firms' stock return risk and increase return/risk ratio. Therefore, stocks dominate options of CEO compensation program in the view of risk-taking. This result can explain why stock compensation is more and more popular and option compensation is less and less on CEO compensation structure.

The remainder of the paper is organized as follows. The next section analyzes the time trend of the structure of CEO equity-based compensation and Section 3 discusses the related literature. Section 4 presents the methodology and date description. Section 5 discusses the empirical results. Section 6 concludes.

\section{Time Trend of the Structure of CEO Equity-Based Compensation}

After collecting compensation data in Compustat database, we first analyzed the different components of CEO compensation, which is in Table 1. In Table 1, column (1), the percentage of salary compensation (defined as the dollar value of the base salary divided by total compensation) is highest for 2009 , but in general, it is a more stable component compared to stock or option compensation. In column (2), the percentage of bonus compensation (defined as the dollar value of a bonus divided by total compensation) is decreasing from 2006 to 2012 . In column (3), the percentage of stock compensation is increasing continuously. In contrast, in column (5), the percentage of option compensation is decreasing. This trend, the increase of stocks and the decrease of options, arises our interests.

The focus of our research is on the equity-based compensation, including stock and option compensation. Therefore, for these two kinds of compensation, we neglected firms without paying by stock compensation (the percentage of stock compensation is $0 \%$ ) and neglect firms without paying by option compensation (the percentage of options is $0 \%$ ) and redo the percentages of stock compensation and option compensation. In column (4), the percentage of stock compensation is also increasing, from $35.7 \%$ in 2006 to $43.5 \%$ in 2012. In column (6), the percentage of option compensation is decreasing, again, from $36.0 \%$ in 2006 to $29.7 \%$ in 2012. To conclude, this trend that stocks are rising and options are decreasing also exists even 
if we neglect firms without paying by stocks or options. Moreover, in this paper, we found that the percentage of firms paying their CEOs with more stock compensation than option compensation (the percentage of stock compensation is higher than option compensation) is rising dramatically, too. Table 2 presents the time trend of the percentages of firms paying their CEOs with stocks or options. In column (1), this percentage rises from 35.0\% in 2006 to $61.9 \%$ in 2012. This statistics show that the stock compensation plays a more dominant role in CEO compensation from 2006 to 2012. Similarly, in column (2), the percentage of firms paying their CEOs only by stocks and other components, without options, is rising dramatically, too, from $19.6 \%$ in 2006 to $35.0 \%$ in 2012. In contrast, in column (3), the percentage of firms paying their CEOs only by options and other components, without stocks, is decreasing, from $19.3 \%$ in 2006 to $12.0 \%$ in 2012. Besides, in column (4), the percentage of firms paying their CEOs by stocks (regardless of the percentages of other compensation components) is rising largely, from 53.3\% in 2006 to $80.2 \%$ in 2012. This trend is consistent with recent researches. For example, Andergassen (2008) indicate that the proportion of pay through options has declined and Tang (2008) also mention that restricted stock plays a more and more dominant role in compensation packages for many firms.

Table 1. Time trend of the structure of CEO compensation

\begin{tabular}{|c|c|c|c|c|c|c|c|c|}
\hline & $\begin{array}{c}(1) \\
\text { Salary } \\
(\%)\end{array}$ & $\begin{array}{c}(2) \\
\text { Bonus } \\
(\%)\end{array}$ & $\begin{array}{c}\text { Stocks } \\
(\%)\end{array}$ & $\begin{array}{c}\text { Stocks }(\%) \\
\text { (excluding firms } \\
\text { without paying } \\
\text { stocks })\end{array}$ & $\begin{array}{c}(5) \\
\text { Options } \\
(\%)\end{array}$ & $\begin{array}{c}(6) \\
\text { Options (\%) } \\
\text { (excluding firms } \\
\text { without paying } \\
\text { options })\end{array}$ & $\begin{array}{c}(7) \\
\text { Others } \\
(\%) *\end{array}$ & $\begin{array}{c}(8) \\
\text { Total } \\
(\%)\end{array}$ \\
\hline 2006 & 28.1 & 8.5 & 17.3 & 35.7 & 17.3 & 36.0 & 28.8 & 100.0 \\
\hline 2007 & 28.8 & 5.0 & 22.6 & 39.0 & 20.3 & 36.8 & 23.3 & 100.0 \\
\hline 2008 & 30.2 & 4.2 & 24.4 & 40.0 & 20.4 & 36.2 & 20.8 & 100.0 \\
\hline 2009 & 30.9 & 4.4 & 23.3 & 37.3 & 18.9 & 33.3 & 22.5 & 100.0 \\
\hline 2010 & 24.6 & 4.2 & 26.1 & 37.5 & 18.2 & 31.7 & 26.9 & 100.0 \\
\hline 2011 & 24.7 & 3.5 & 29.9 & 41.8 & 17.7 & 32.1 & 24.2 & 100.0 \\
\hline 2012 & 25.1 & 3.2 & 32.2 & 43.5 & 15.2 & 29.7 & 24.3 & 100.0 \\
\hline
\end{tabular}

*The definition of total compensation (TDC1) in ExecuComp is the amount comprised of salary, bonus, non-equity incentive plan compensation, grant-date fair value of option awards, grant-date fair value of stock awards, deferred compensation earnings reported as compensation, and other compensation. This table does not include non-equity incentive plan compensation and deferred compensation earnings reported as compensation because of the incompleteness of ExecuComp database. Most of these two items are zero or empty. Therefore, the percentage of others is high, about $20 \%$ to $26 \%$.

Table 2. Time trend of the percentages of firms paying their CEOs with stocks or options 


\begin{tabular}{|c|c|c|c|c|c|c|}
\hline & $\begin{array}{c}(1) \\
\text { With more } \\
\text { stocks (\%) }\end{array}$ & $\begin{array}{c}\text { With only stocks, } \\
\text { without options (\%) }\end{array}$ & $\begin{array}{c}\text { With only options, } \\
\text { without stocks (\%) }\end{array}$ & $\begin{array}{c}(4) \\
\text { With } \\
\text { stocks } \\
(\%)\end{array}$ & $\begin{array}{c}(5) \\
\text { With } \\
\text { options } \\
(\%)\end{array}$ & $\begin{array}{c}\text { With both stocks } \\
\text { and options }(\%)\end{array}$ \\
\hline 2006 & 35.0 & 19.6 & 19.3 & 48.3 & 48.1 & 28.7 \\
\hline 2007 & 43.5 & 24.5 & 21.7 & 58.0 & 55.2 & 33.5 \\
\hline 2008 & 46.1 & 25.6 & 20.9 & 61.1 & 56.4 & 35.5 \\
\hline 2009 & 45.9 & 24.9 & 19.4 & 62.5 & 56.9 & 37.5 \\
\hline 2010 & 54.4 & 28.8 & 16.5 & 69.6 & 57.3 & 40.8 \\
\hline 2011 & 56.7 & 30.9 & 14.7 & 71.5 & 55.2 & 40.5 \\
\hline 2012 & 61.9 & 35.0 & 12.0 & 74.0 & 50.9 & 39.0 \\
\hline
\end{tabular}

(1) This item represents the percentage of firms paying their CEOs with higher percentage of stocks than options.

(2) This item represents the percentage of firms paying their CEOs with only stocks and other components, but without options. (The percentage of options is $0 \%$ ) (3) This item represents the percentage of firms paying their CEOs with only options and other components, but without stocks. (The percentage of stocks is 0\%) (4) This item represents the percentage of firms paying their CEOs with stocks (the percentage of stocks is higher than 0\%), regardless of the percentages of other components. (5) This item represents the percentage of firms paying their CEOs withoptions (the percentage of options is higher than 0\%), regardless of the percentages of other components. (6) This item represents the percentage of firms paying their CEOs with both stocks and options (the percentages of stocks and options are higher than $0 \%$ ), regardless of the percentages of other components.

\section{Literature Review}

Whether stocks or options are better compensation instruments is not clear in the extant literature. Despite the popularity of equity-based compensation, there is considerable controversy about this kind of compensation in many papers.

First, we review some papers showing that option compensation is a better component in CEO compensation. Lambert and Larcker (2004) use agency theory to model the optimal mix of options and stock in the compensation contract. They show that restricted stock is generally not the optimal contract form, and that option-based contracts with positive exercise prices have both efficiency and incentive advantages. Palmon et al. (2008) argue that, through simulating the manager's effort choice and compensation as well as the value of shareholders' equity, when abstracting from tax considerations, it is optimal to award managers with options that will most likely be highly valuable (i.e., substantially in-the-money) on their expiration date. Wu (2011) develops an agency model to analyze the optimality of executive stock option compensation in the presence of information manipulation. The analyses show that an optimal executive compensation package includes stock options instead of restricted stocks under most circumstances. Cadenillas et al. (2004) study the incentive effects of debt on a risk-averse manager in a dynamic continuous time framework. They suggest that options are optimal for managers that are more effective in affecting firmvalue through effort, and in firms with high momentum, large firms, and firms for which additional volatility implies a small decrease in returns. Smith and Stulz (1985) also show that because managers have significant human capital tied to the firm and are less diversified compared with outside shareholders, they could give up risk-increasing positive net present value projects that would be beneficial to shareholders. Shareholders can potentially reduce this risk-related agency problem by structuring compensation to be a convex function of firm performance (e.g., through the use of 
stock options), which makes the manager's expected wealth an increasing function of volatility.

Second, there are also some researches showing that stock compensation dominates option compensation. For example, Hall and Murphy (2002) show that restricted stock dominates options by analyzing the cost, value and pay/performance sensitivity of non-tradable options held by undiversified, risk-averse executives. Moreover, Hayes et al. (2012) measure how pay-performance sensitivity (delta) and convexity (vega) in compensation change around FAS 123R. They find out the changes in pay-performance sensitivity are relatively away from stock options toward other forms of performance-based pay. Therefore, their result is consistent with Hall and Murphy (2002).

Third, some researchers claim that whether stock compensation or option compensation is better depends on different conditions. For example, Feltham and $\mathrm{Wu}$ (2001) show that, when the agent affects only the mean of the outcome, restricted stock contracts dominate option-based contracts. Conversely, option-based contracts dominate restricted stock contracts. Kadan and Swinkels (2008) show that stocks can dominate options as a means of motivation only if non-viability risk is substantial, as in financially distressed firms or start-ups. Options dominate stocks for other firms. Moreover, they provide empirical evidence that higher bankruptcy risk is indeed correlated with more use of stock.

One of the results of our research is on the determinants of CEO compensation, so we also review some empirical literature on the determinants of executive compensation. For example, Smith and Watts (1992) show that large and nonregulatedfirms and firms with more growth opportunities have higher levels of executive compensation. Gaver and Gaver (1993) find that growth firms pay higher level of cash compensation to their executives. Controlling firm size, they show that the incidence of bonus plans, performance plans, and restricted stock plans does not differ between growth and non-growth firms. Kole (1997) shows that restricted stock is most prevalent among research-intensive firms and firms in innovative industries. Barron and Waddell (2003) show that executive rank is a major determinant of the extent of use of incentive pay.Bryan et al. (2000) examine the mix, incentive intensity, and economic determinants of stock-based compensation. They show that firms with high leverage ratios tend to grant their managers more restricted stock.

\section{Methodology}

\subsection{Sample Selection}

Our sample firms are collected from the ExecuComp database, which contains the compensation information about firms that belong to the S\&P 1500 index, or that once belonged to this index. First, we searched the entire database and eliminate the financial institutions (SIC code between 6000-6999), because they are subject to different regulatory requirements and have distinctly different financial characteristics. Most recently in 2006, the FAS $123 \mathrm{R}$ changed the reporting requirements of the DEF14A form. Under this new reporting regime, the cost of all employee stock options, as well as other equity-based compensation arrangements have to be reflected in the financial statements based on the estimated fair value 
of the awards. Furthermore, Hayes et al. (2012) show that all firms dramatically reduce their usage of stock options (convexity) after the adoption of FAS $123 \mathrm{R}$ and that the decline in option use is strongly associated with a proxy for accounting costs. Therefore, we set the sample period from 2006 to 2012.

Second, we collected CEO compensation data from ExecuComp in Compustat database, financial information and firm characteristics from Compustat database. The financial information consists of $95.6 \%$ sample.

Third, we collected the monthly stock return data from CRSP database in order to calculate the yearly stock return and stock return volatility, and it consists of $90.3 \%$ sample. Lastly, we also include some corporate governance variables from RiskMetrics database in order to construct the entrenchment index ${ }^{1}$.

To summarize, the final sample comprises 9,223 firm-year observations, including 1,700 different non-financial institutions from 2006 to 2012.

\subsection{Sample Distribution}

Table 3presents the total sample distribution categorized by years (panel A) and by industries (panel B). In panel A, for 2006 only, the number of firms is relatively low compared to other years. For 2007 to 2012, the number of firms is stable. We control years for most of regressions.

In panel B, the three biggest industries are manufacturing, services, and transportation, totally accounting for $79.1 \%$ of the total sample. We control industries for every regression.

Table 3. Sample distribution (categorized by years and industries)

\begin{tabular}{|l|l|c|c|}
\hline \multicolumn{2}{|l|}{ panel A: Categorized by years } & Amount & Percentage (\%) \\
\hline Year & & 1,030 & 11.2 \\
\hline 2006 & & 1,310 & 14.2 \\
\hline 2007 & & 1,357 & 14.7 \\
\hline 2008 & & 1,368 & 14.8 \\
\hline 2009 & & 1,369 & 14.8 \\
\hline 2010 & & 1,419 & 15.4 \\
\hline 2011 & & 1,370 & 14.9 \\
\hline 2012 & & 9,223 & 100 \\
\hline Total & \multicolumn{2}{|c|}{} \\
\hline panel A: Categorized by industries & Amount & Percentage $(\%)$ \\
\hline SIC Code & Industry & 34 & 0.4 \\
\hline $100 \sim 700$ & Agriculture & 507 & 5.5 \\
\hline $1000 \sim 1499$ & Mining & 158 & 1.7 \\
\hline $1500 \sim 1999$ & Construction & 4,538 & 49.2 \\
\hline $2000 \sim 3999$ & Manufacturing & 1,087 & 11.8 \\
\hline $4000 \sim 4999$ & Transportation & 324 & 3.5 \\
\hline $5000 \sim 5199$ & Wholesale Trade & 861 & 9.3 \\
\hline $5200 \sim 5999$ & Retail Trade & 1,673 & 18.1 \\
\hline $7000 \sim 8999$ & Services & 41 & 0.4 \\
\hline $9000 \sim 9999$ & Public Administration & 9,223 & 100 \\
\hline Total & \multicolumn{2}{|l|}{} \\
\hline
\end{tabular}

${ }^{1}$ Compustat, ExecuComp, and RiskMetrics databases collected complete financial information, compensation data and corporate governance variables, respectively. These three databases were commonly used on finance research. 


\subsection{Data Descriptions}

\subsubsection{Definitions of Variables}

\section{a. Measurement of CEO compensation}

Table 4 presents the definitions of all variables in our research. In this research, the total CEO compensation consists of four main components, which are salary, bonus, stocks, and options. In order to compare the level of compensation among different companies and different years, we use the percentages of each compensation component to do our analysis. The following definitions are based on the ExecuComp data definitions.

For the part of fixed CEO pay, the definition of salary is the dollar value of the base salary earned by the named executive officer during the fiscal year. So, the percentage of salary compensation is salary scaled by total compensation. The definition of bonus is the dollar value of a bonus earned by the named executive officer during the fiscal year. Also, the percentage of bonus compensation is bonus scaled by total compensation.

For the part of variable CEO pay, stock compensation includes restricted stock, restricted stock units, phantom stock, phantom stock units, and common stock equivalent units. Option compensation includes options, stock appreciation rights, and other instruments with option-like features. The valuation method of these two components is based on the grant-date fair value as detailed in FAS123R. For restricted stock, fair value was calculated using the closing price of common stock on the grant date. For options, fair value was calculated using the Black-Scholes value on the grant date. The percentage of stock compensation is the grant-date fair value of stock scaled by total compensation, and the percentage of option compensation is the grant-date fair value of option scaled by total compensation.

For total compensation, the definition is the summary of salary, bonus, other annual, total value of stocks granted, total value of options granted (using Black-Scholes), long-term incentive payouts, and all other total.

\section{b. Measurement of $\mathrm{CEO}$ variables}

There are three kinds of variables in this category. Rank First is a dummy variable which takes a value of 1 if the sum of salary and bonus of this CEO is ranked first among managers and zero otherwise. Duality is another dummy variable which takes a value of 1 if this CEO is also the chairman of the board of directors and zero otherwise. Male is also a dummy variable which takes a value of 1 if the $\mathrm{CEO}$ is male and zero otherwise.

\section{c. Measurement of firm characteristics}

Market to book ratio (MB) is measured by the firm's market value of shareholders' equity (MV) divided by the book value of shareholders' equity. MV is defined as the close price for the fiscal year multiplied by the company's common shares outstanding. Asset is used to control firms' size. Asset is defined as the total assets as reported by the company. Lin et al. (2013) show that the market to book ratio and firm size are significantly related to CEO compensation. Debt ratio is defined by total liabilities divided by the sum of total liabilities and the market value of 
equity. We use ROA to present firms' profitability. ROA is defined as the net income divided by total assets. Current ratio (Current) is defined as current assets divided by current liabilities.

Return is defined as cumulative 12-month stock returns. Cohen et al., (2007) indicated that annualized stock return significantly affects CEO compensation. Volatility is stock return volatility and measured as the annualized standard deviation of monthly stock return.

Altman's Z-Score is defined as

$$
\mathrm{Z}=1.2 X_{1}+1.4 X_{2}+3.3 X_{3}+0.6 X_{4}+1.0 X_{5}
$$

Where $\mathrm{X} 1$ is net working capital scaled by assets, $\mathrm{X} 2$ is retained earnings scaled by assets, $\mathrm{X} 3$ is pretax earnings scaled by assets, $\mathrm{X} 4$ is market value of equity scaled by book liabilities, and X5 is sales scaled by assets. Kadan and Swinkels (2008) show that higher bankruptcy risk is indeed correlated with more use of stock. Therefore, in our analysis, we use Z-Score and debt ratio as the bankruptcy risk.

\section{d. Measurement of anti-takeover indexes}

Bebchuk et al., (2008) constructed the entrenchment index (E-index) based on six provisions: staggered boards, limits to shareholder bylaw amendments, poison pills, golden parachutes, and supermajority requirements for mergers and charter amendments. The E-index data on authors' website is not sufficient for this paper, so we collect the six provisions from RiskMetrics database and constructed it by ourselves. Staggered boards is a dummy variable which takes a value of 1 if the board of directors of this company has only a fraction (often one third) of the members of the board of directors is elected each time instead of en masse (where all directors have one-year terms) and zero otherwise. Limits to shareholder bylaw amendments is a dummy variable which takes a value of 1 if this company limit shareholders' ability to amend the governing documents of the corporation and zero otherwise. Poison pills is a dummy variable which takes a value of 1 if this company is equipped with this provision of poison pill and zero otherwise. Golden parachutes is a dummy variable which takes a value of 1 if substantial benefits given to a top executive (or top executives) in the event that the company is taken over by another firm and the executive is terminated as a result of the merger or takeover and zero otherwise. Supermajority requirements for mergers is a dummy variable which takes a value of 1 if a corporate amendment in a company's charter requiring a large majority (anywhere from 67-90\%) of shareholders to approve a merger. Supermajority requirements for charter amendments is a dummy variable which takes a value of 1 if a corporate amendment in a company's charter requiring a large majority (anywhere from $67-90 \%$ ) of shareholders to approve a charter amendments. Finally, the E-index is constructed by adding the six dummy variables, so the range of E-index number is from 0 to 6 .

Table 4. Definition of all variables

\begin{tabular}{|l|l|}
\hline Variables & \\
\hline a. Compensation Variables & Definition \\
\hline Salary $(\%)$ & The dollar value of the base salary divided by total compensation \\
\hline Bonus $(\%)$ & The dollar value of a bonus divided by total compensation \\
\hline
\end{tabular}




\begin{tabular}{|c|c|}
\hline Stock $(\%)$ & Fair value of all stock awards divided by total compensation \\
\hline Option (\%) & Fair value of all options awarded divided by total compensation \\
\hline Total Compensation $(\$)$ & $\begin{array}{l}\text { The sum of salary, bonus, grant-date fair value of stock awards, } \\
\text { grant-date fair value of option awards, deferred compensation, and } \\
\text { other compensation }\end{array}$ \\
\hline \multicolumn{2}{|l|}{ b. CEO Characteristics } \\
\hline Rank_First & $\begin{array}{l}\text { A dummy variable is } 1 \text { if this CEO is No.1 based on salary and } \\
\text { bonus in his/her company }\end{array}$ \\
\hline Duality & $\begin{array}{l}\text { A dummy variable is } 1 \text { if this CEO is also the chairman of the board } \\
\text { of directors }\end{array}$ \\
\hline Male & A dummy variable is 1 if the CEO is male \\
\hline \multicolumn{2}{|l|}{ c. Firm Characteristics } \\
\hline Return & Cumulative 12 month stock returns \\
\hline Volatility & Annualized standard deviation of monthly stock returns \\
\hline Z-Score & $\begin{array}{l}\mathrm{Z}=1.2 \mathrm{X} 1+1.4 \mathrm{X} 2+3.3 \mathrm{X} 3+0.6 \mathrm{X} 4+1.0 \mathrm{X} 5 \text {, where } \mathrm{X} 1 \text { is net } \\
\text { working capital scaled by assets, } \mathrm{X} 2 \text { is retained earnings scaled by } \\
\text { assets, } \mathrm{X} 3 \text { is pretax earnings scaled by assets, } \mathrm{X} 4 \text { is market value of } \\
\text { equity scaled by book liabilities, and } \mathrm{X} 5 \text { is sales scaled by assets. }\end{array}$ \\
\hline Debt Ratio (Market) & $\begin{array}{l}\text { Total liabilities divided by the sum of total liabilities and the market } \\
\text { value of equity }\end{array}$ \\
\hline ROA & The net income divided by total assets \\
\hline Asset & The total assets as reported by the company \\
\hline MV (Market value) & $\begin{array}{l}\text { The close price for the fiscal year multiplied by the company's } \\
\text { common shares outstanding }\end{array}$ \\
\hline MB & Market value divided by book value of shareholders' equity \\
\hline Current & Current assets divided by current liabilities \\
\hline \multicolumn{2}{|l|}{ d. Anti-takeover Indexes } \\
\hline E-index & $\begin{array}{l}\text { Staggered boards, limits to shareholder bylaw amendments, poison } \\
\text { pills, golden parachutes, and supermajority requirements for } \\
\text { mergers and charter amendments }\end{array}$ \\
\hline
\end{tabular}

1, 2: These two variables are for financial institutions only, and all other variables are for both non-financial and financial institutions.

\subsubsection{Descriptive Statistics}

Table 5presents the descriptive statistics. In Table 5, for all the variables, they consist above $90 \%$ of the total sample. The mean of the percentage of stock compensation is $25.44 \%$, which is higher than the median, $22.55 \%$, representing that the pay of highest-paid CEOs is extremely high. This phenomenon is especially obvious for option compensation, which has $8 \%$ gap between stock compensation and option compensation. In our common sense, CEOs receive the highest pay among all the executives, but Rank First tells us that CEOs who receive the highest salary and bonus only accounts for about $73 \%$. About half of the CEOs are also the chairman of the board of directors. $96 \%$ of the CEOs are male.

Table 5. Descriptive Statistics

\begin{tabular}{|l|c|c|c|c|c|c|}
\hline & $\mathrm{N}$ & Mean & $\begin{array}{c}\text { Standard } \\
\text { Deviation }\end{array}$ & $\mathrm{Q} 1$ & Median & Q3 \\
\hline a. Dependent Variables & & & & & & \\
\hline Stock (\%) & 9,223 & 25.44 & 24.98 & 0 & 22.55 & 44.09 \\
\hline Option (\%) & 9,223 & 18.3 & 22.24 & 0 & 10.61 & 31.16 \\
\hline b. CEO Characteristics & & & & & & \\
\hline Rank_First (dummy) & 9,223 & 0.73 & 0.44 & 0 & 1 & 1 \\
\hline
\end{tabular}




\section{Macrothink}

Business and Economic Research ISSN 2162-4860

2014, Vol. 4, No. 2

\begin{tabular}{|l|c|c|c|c|c|c|}
\hline Duality (dummy) & 9,223 & 0.43 & 0.50 & 0 & 0 & 1 \\
\hline Male (dummy) & 9,223 & 0.96 & 0.19 & 1 & 1 & 1 \\
\hline c. Firm Characteristics & & & & & & \\
\hline Z-Score & 8,767 & 4.80 & 8.04 & 1.88 & 3.34 & 5.55 \\
\hline Yearly Stock Return & 8,254 & 0.12 & 0.48 & -0.11 & 0.12 & 0.34 \\
\hline $\begin{array}{l}\text { Annualized Stock Return } \\
\text { Volatility }\end{array}$ & 8,254 & 0.19 & 0.11 & 0.12 & 0.16 & 0.23 \\
\hline Debt Ratio (Market) & 8,797 & 0.37 & 0.25 & 0.17 & 0.32 & 0.52 \\
\hline ROA of Euity & 8,799 & $7,763.38$ & $25,393.27$ & 555.48 & $1,563.63$ & $4,718.68$ \\
\hline Asset (\$ millions) & 8,799 & $9,356.45$ & $47,714.17$ & 592.31 & $1,730.18$ & $5,589.93$ \\
\hline $\begin{array}{l}\text { Market Value } \\
\text { \$ millions) }\end{array}$ & 8,798 & 3.26 & 10.44 & 1.34 & 2.10 & 3.40 \\
\hline Market to Book Ratio & 8,420 & 2.50 & 2.70 & 1.32 & 1.93 & 2.87 \\
\hline $\begin{array}{l}\text { Current Ratio } \\
\text { d. Anti-takeover Indexes }\end{array}$ & 9,223 & 2.01 & 1.63 & 0.00 & 2 & 3 \\
\hline E-index & & & & & \\
\hline
\end{tabular}

4.3.3 Correlations between Independent Variables and Dependent Variables

Table 6 presents the Pearson correlations between the change of independent variables and the change of dependent variables. The independent variables (the percentage of stocks, options, and stock-minus-option compensation) are $\mathrm{t}-(\mathrm{t}-1)$, and the dependent variables (CEO characteristics, firm characteristics and entrenchment index) are lagged for one year, $(\mathrm{t}-1)-(\mathrm{t}-2)$.

In column (1), we could tell that stocks and options are negatively correlated. Return, Z-score, ROA, size, market-to-book ratio and entrenchment index are positively correlated with stocks, and debt ratio is negatively correlated with stocks.

Table 6. Pearson Correlations between independent variables and dependent variables for non-financial institutions

Statistical significance at the $10 \%, 5 \%$, and $1 \%$ level is indicated by $* * *$, and ***, respectively. P-value are also presented below estimates.

\begin{tabular}{|c|c|c|c|}
\hline Pearson Correlations & (1) & (2) & (3) \\
\hline Variables & $\Delta \operatorname{Stock}(\%)_{\mathrm{t}-(\mathrm{t}-1)}$ & $\Delta$ Option $(\%)_{\mathrm{t}-(\mathrm{t}-1)}$ & $\begin{array}{c}\Delta(\text { Stock }(\%)-O p t i o n(\%)) \\
\mathrm{t}-(\mathrm{t}-1)\end{array}$ \\
\hline$\Delta$ Stock $(\%)_{\mathrm{t}-(\mathrm{t}-1)}$ & $\begin{array}{l}1.000 * * * \\
(0.000)\end{array}$ & & \\
\hline$\Delta$ Option $(\%)_{\mathrm{t}-\mathrm{t}-1)}$ & $\begin{array}{c}-0.168 * * * \\
(0.000)\end{array}$ & $\begin{array}{l}1.000 * * * \\
(0.000)\end{array}$ & \\
\hline $\begin{array}{l}\Delta(\text { Stock }(\%)- \\
\text { Option }(\%))_{\mathrm{t}-(\mathrm{t}-1)}\end{array}$ & $\begin{array}{l}0.762 * * * \\
(0.000)\end{array}$ & $\begin{array}{c}-0.663 * * * \\
(0.000)\end{array}$ & $\begin{array}{c}1.000 * * * \\
(0.000)\end{array}$ \\
\hline$\Delta$ Rank_First $_{(\mathrm{t}-1)-(\mathrm{t}-2)}$ & $\begin{array}{l}-0.017 \\
(0.146)\end{array}$ & $\begin{array}{c}-0.027 * * \\
(0.021)\end{array}$ & $\begin{array}{c}0.013 \\
(0.276)\end{array}$ \\
\hline$\Delta$ Duality $_{(\mathrm{t}-1)-(\mathrm{t}-2)}$ & $\begin{array}{c}-0.035^{* * * *} \\
(0.003) \\
\end{array}$ & $\begin{array}{c}0.024 * * \\
(0.037) \\
\end{array}$ & $\begin{array}{c}-0.039 * * * \\
(0.001) \\
\end{array}$ \\
\hline$\Delta$ Male $_{(\mathrm{t}-1)-(\mathrm{t}-2)}$ & $\begin{array}{l}-0.001 \\
(0.962) \\
\end{array}$ & $\begin{array}{l}-0.013 \\
(0.266)\end{array}$ & $\begin{array}{c}0.012 \\
(0.319) \\
\end{array}$ \\
\hline$\Delta \operatorname{Return}_{(\mathrm{t}-1)-(\mathrm{t}-2)}$ & $\begin{array}{l}0.049 * * * \\
(0.000)\end{array}$ & $\begin{array}{c}0.001 \\
(0.964)\end{array}$ & $\begin{array}{c}0.034 * * * \\
(0.005)\end{array}$ \\
\hline$\Delta$ Volatility $_{(\mathrm{t}-1)-(\mathrm{t}-2)}$ & $\begin{array}{l}-0.045^{* * *} \\
(0.000)\end{array}$ & $\begin{array}{c}0.017 \\
(0.169)\end{array}$ & $\begin{array}{l}-0.031 * * \\
(0.011)\end{array}$ \\
\hline$\Delta \mathrm{Z}-$ Score $_{(\mathrm{t}-1)-(\mathrm{t}-2)}$ & $0.030 * *$ & 0.015 & 0.006 \\
\hline
\end{tabular}




\begin{tabular}{|l|c|c|c|}
\hline & $(0.013)$ & $(0.213)$ & $(0.605)$ \\
\hline$\Delta$ Debt Ratio $_{(\mathrm{t}-1)-(\mathrm{t}-2)}$ & $-0.039^{* * *}$ & -0.010 & -0.017 \\
& $(0.001)$ & $(0.418)$ & $(0.148)$ \\
\hline$\Delta$ ROA $_{(\mathrm{t}-1)-(\mathrm{t}-2)}$ & $0.062^{* * *}$ & 0.012 & $0.024 * *$ \\
& $(0.000)$ & $(0.304)$ & $(0.044)$ \\
\hline$\Delta \ln$ Asset) $_{(\mathrm{t}-1)-(\mathrm{t}-2)}$ & $0.045^{* * *}$ & $0.030^{* *}$ & 0.014 \\
& $(0.000)$ & $(0.014)$ & $(0.232)$ \\
\hline$\Delta$ Market to Book Ratio $_{(\mathrm{t}-1)-(\mathrm{t}-2)}$ & $0.048^{* * *}$ & 0.005 & $0.022^{*}$ \\
& $(0.000)$ & $(0.660)$ & $(0.065)$ \\
\hline$\Delta$ Current Ratio $_{(\mathrm{t}-1)-(\mathrm{t}-2)}$ & -0.007 & -0.003 & $(0.093)$ \\
\hline$\Delta$ E-index $_{(\mathrm{t}-1)-(\mathrm{t}-2)}$ & $(0.564)$ & $(0.780)$ & 0.011 \\
& $0.042^{* * *}$ & $0.035^{* * *}$ & $(0.357)$ \\
\hline
\end{tabular}

\section{Results}

\subsection{The Change of CEO Equity-Based Compensation Structure and the Determinants of CEO Compensation}

One of our focuses is on the determinants of the change of CEO equity-based compensation. We start our analysis by regressing measures of equity-based compensation on CEO characteristics, firm characteristics, and the anti-takeover index (E-index). First, we make every variable of one single year and single firm deducted by the last-year corresponding variable. All the dependent variables are lagged for one year in order to eliminate the endogeneity problem, which is not seriously taken into account in this paper. To sum up, the measures of independent variables are $\mathrm{t}-(\mathrm{t}-1)$, and the measures of dependent variables are $(\mathrm{t}-1)-(\mathrm{t}-2)$. For example, if one observation is the stock compensation in 2012 deducted by the stock compensation in 2011, its corresponding observations are the dependent variables in 2011 deducted by the dependent variables in 2010. In order to compare results between different measures of equity-based compensation, we explain the results of Table 7, 8, and 9 together. Table 7, 8, and 9 present the OLS regressions on the change of stock compensation, option compensation, and stock-minus-option compensation.

In Table 7 and 9, the change of CEO duality is negatively correlated with the percentage of stock or stock-minus-option compensation relative to last year. This represents if a CEO is also the chairman of the board of directors, he/she would receive less stock compensation. We interpret this result as when there is a supervision mechanism (when the CEO is not also the chairman), CEOs will receive more stock compensation.

In Table 7 and 8, in contrast, the change of stock return is positively correlated with the percentage of stock compensation relative to last year, but it is not significantly correlated with the percentage of option compensation relative to last year. We interpret this as stock compensation is more related to stock return performance (more "pay-by-performance") than option compensation.

In Table 9, column (3), the change of debt ratio is negatively correlated with the percentage of stock-minus-option compensation relative to last year. This represents that stock compensation is a better component for firms whose probability of non-viability risk is higher. This result corresponds with Kadan and Swinkels (2008). They show that if non-viability is a major issue, 
stocks always dominate stock options. The intuition for this result is quite simple. If the probability of the non-viability risk is non-negligible, that is the stock price of this company may be close to zero. Therefore, paying CEOs with stocks is a better choice because stock can make the manager's income responsive to stock price changes at low levels of the stock price, improving the incentives of the manager to make appropriate choices. Also, they also predicta drawback of this condition. The drawback is that doing so may make the manager very wealthy at more normal stock prices.

In Table 7 and Table 9, column (1) and (2), the change of size is positively correlated with both the percentage of stock or stock-minus-option compensation relative to last year. Smith and Watts (1992) also show that large and non-regulatedfirms and firms with more growth opportunities have higher levels of executive compensation.

In Table 7 and Table 8, column (1) and (2), the change of entrenchment index is positively correlated with the percentage of stock and option compensation relative to last year. We interpret this result as followings. If the entrenchment index of firms becomes higher, that is, firms are more anti-takeover, then firms would pay more stocks and options to their CEOs. Therefore, the share holdings of CEOs would be higher, making the power of CEO enlarged.

In Table 7, column (1) and Table 8, column (1) and (2), the change of current ratio is positively correlated with the percentage of stock compensation relative to last year, but it is negatively correlated with the percentage of option compensation relative to last year.

Table 7. The relation between the change of stock compensation and the changes of dependent variables

\begin{tabular}{|c|c|c|}
\hline & \multicolumn{2}{|c|}{$\Delta$ Stock $(\%)_{\mathrm{t}-(\mathrm{t}-1)}$} \\
\hline Variables & (1) & (2) \\
\hline Intercept & $\begin{array}{c}0.026^{* * *} * \\
(8.769)\end{array}$ & $\begin{array}{c}0.026^{* * *} \\
(8.875)\end{array}$ \\
\hline$\Delta \operatorname{Return}_{(\mathrm{t}-1)-(\mathrm{t}-2)}$ & $\begin{array}{c}0.014 * * * \\
(3.572)\end{array}$ & $\begin{array}{c}0.013^{* * * *} \\
(3.300)\end{array}$ \\
\hline$\Delta Z_{-}$Score $_{(\mathrm{t}-1)-(\mathrm{t}-2)}$ & $\begin{array}{c}-0.001 \\
(-1.547)\end{array}$ & \\
\hline$\Delta$ Debt Ratio $_{(\mathrm{t}-1)-(\mathrm{t}-2)}$ & & $\begin{array}{c}-0.009 \\
(-0.564)\end{array}$ \\
\hline$\Delta \mathrm{ROA}_{(\mathrm{t}-1)-(\mathrm{t}-2)}$ & & $\begin{array}{c}-0.003 \\
(-0.132)\end{array}$ \\
\hline$\Delta \operatorname{Size}_{(\mathrm{t}-1)-(\mathrm{t}-2)}$ & $\begin{array}{c}0.006 * * * \\
(2.881) \\
\end{array}$ & $\begin{array}{c}0.007 * * * \\
(3.146)\end{array}$ \\
\hline$\Delta$ Market to Book Ratio $_{(\mathrm{t}-1)-(\mathrm{t}-2)}$ & $\begin{array}{c}0.000 \\
(0.816)\end{array}$ & $\begin{array}{c}0.000 \\
(0.704)\end{array}$ \\
\hline$\Delta \mathrm{E}^{-i n d e x}{ }_{(\mathrm{t}-1)-(\mathrm{t}-2)}$ & $\begin{array}{c}0.009 * * * \\
(3.828)\end{array}$ & $\begin{array}{c}0.009 * * * \\
(3.854)\end{array}$ \\
\hline$\Delta$ Current Ratio $_{(\mathrm{t}-1)-(\mathrm{t}-2)}$ & $\begin{array}{c}0.004 * * \\
(2.074)\end{array}$ & $\begin{array}{c}0.002 \\
(1.243)\end{array}$ \\
\hline$\Delta$ Rank_First $_{(\mathrm{t}-1)-(\mathrm{t}-2)}$ & $\begin{array}{l}-0.015^{*} \\
(-1.937)\end{array}$ & $\begin{array}{l}-0.015^{*} \\
(-1.936)\end{array}$ \\
\hline$\Delta$ Duality $_{(\mathrm{t}-1)-(\mathrm{t}-2)}$ & $\begin{array}{c}-0.013 * * * \\
(-3.245) \\
\end{array}$ & $\begin{array}{c}-0.013 * * * \\
(-3.256) \\
\end{array}$ \\
\hline$\Delta$ Male $_{(\mathrm{t}-1)-(\mathrm{t}-2)}$ & -0.006 & -0.002 \\
\hline
\end{tabular}




\begin{tabular}{|l|c|c|}
\hline & $(-0.375)$ & $(-0.098)$ \\
\hline Year Dummies & & YES \\
\hline Industry Dummies & YES & YES \\
\hline $\mathrm{R}$ square & YES & $0.80 \%$ \\
\hline $\mathrm{n}$ & $0.90 \%$ & 5,766 \\
\hline
\end{tabular}

Statistical significance at the $10 \%, 5 \%$, and $1 \%$ level is indicated by $*, * *$, and ***, respectively. T-statistics are also presented below estimates.

Table 8 . The relation between the change of option compensation and the changes of dependent variables

\begin{tabular}{|c|c|c|}
\hline & \multicolumn{2}{|c|}{$\Delta$ Option $(\%)_{\mathrm{t}-(\mathrm{t}-1)}$} \\
\hline Variables & $(1)$ & $(2)$ \\
\hline Intercept & $\begin{array}{c}-0.006 * * \\
(-2.203) \\
\end{array}$ & $\begin{array}{c}-0.006^{* *} \\
(-2.285) \\
\end{array}$ \\
\hline$\Delta \operatorname{Return}_{(\mathrm{t}-1)-(\mathrm{t}-2)}$ & $\begin{array}{c}0.005 \\
(1.323) \\
\end{array}$ & $\begin{array}{c}0.004 \\
(1.239) \\
\end{array}$ \\
\hline$\Delta Z_{-}-$core $_{(\mathrm{t}-1)-(\mathrm{t}-2)}$ & $\begin{array}{c}0.000 \\
(0.638)\end{array}$ & \\
\hline$\Delta$ Debt Ratio (Market) ${ }_{(\mathrm{t}-1)-(\mathrm{t}-2)}$ & & $\begin{array}{c}-0.005 \\
(-0.338)\end{array}$ \\
\hline$\Delta \mathrm{ROA}_{(\mathrm{t}-1)-(\mathrm{t}-2)}$ & & $\begin{array}{c}0.020 \\
(0.924)\end{array}$ \\
\hline$\Delta \operatorname{Size}_{(\mathrm{t}-1)-(\mathrm{t}-2)}$ & $\begin{array}{c}0.000 \\
(-0.155)\end{array}$ & $\begin{array}{c}0.000 \\
(-0.200) \\
\end{array}$ \\
\hline$\Delta$ Market to Book Ratio $_{(\mathrm{t}-1)-(\mathrm{t}-2)}$ & $\begin{array}{c}0.000 \\
(-0.909)\end{array}$ & $\begin{array}{c}0.000 \\
(-0.939)\end{array}$ \\
\hline$\Delta \mathrm{E}^{-i n d e x}{ }_{(\mathrm{t}-1)-(\mathrm{t}-2)}$ & $\begin{array}{c}0.006 * * * \\
(2.999) \\
\end{array}$ & $\begin{array}{c}0.006^{* * *} * \\
(3.079)\end{array}$ \\
\hline$\Delta$ Current Ratio $(\mathrm{t}-1)-(\mathrm{t}-2)$ & $\begin{array}{c}-0.003 * * \\
(-2.110)\end{array}$ & $\begin{array}{c}-0.003 * * \\
(-2.202)\end{array}$ \\
\hline$\Delta$ Rank_First $_{(\mathrm{t}-1)-(\mathrm{t}-2)}$ & $\begin{array}{c}-0.028 * * * \\
(-3.991) \\
\end{array}$ & $\begin{array}{c}-0.028 * * * \\
(-3.913) \\
\end{array}$ \\
\hline$\Delta$ Duality $_{(\mathrm{t}-1)-(\mathrm{t}-2)}$ & $\begin{array}{c}0.003 \\
(0.701) \\
\end{array}$ & $\begin{array}{c}0.002 \\
(0.655) \\
\end{array}$ \\
\hline$\Delta$ Male $_{(\mathrm{t}-1)-(\mathrm{t}-2)}$ & $\begin{array}{l}-0.023 \\
(0.122) \\
\end{array}$ & $\begin{array}{c}-0.023 \\
(-1.541) \\
\end{array}$ \\
\hline Year Dummies & YES & YES \\
\hline Industry Dummies & YES & YES \\
\hline $\mathrm{R}$ square & $0.60 \%$ & $0.60 \%$ \\
\hline $\mathrm{n}$ & 5,731 & 5,766 \\
\hline
\end{tabular}

Table 9. The relation between the change of stock-minus-option compensation and the changes of dependent variables

\begin{tabular}{|l|c|c|}
\hline & \multicolumn{2}{|c|}{$\Delta($ Stock $(\%)-$ Option $(\%)) \mathrm{t}-(\mathrm{t}-1)$} \\
\hline Variables & $(1)$ & $(2)$ \\
\hline Intercept & $0.032^{* * *}$ & $0.032^{* * *}$ \\
& $(7.115)$ & $(7.219)$ \\
\hline Return $_{(\mathrm{t}-1)-(\mathrm{t}-2)}$ & $0.010^{* *}$ & $0.008^{* *}$ \\
& $(2.508)$ & $(2.495)$ \\
\hline
\end{tabular}




\section{Macrothink}

Business and Economic Research ISSN 2162-4860 2014, Vol. 4, No. 2

\begin{tabular}{|c|c|c|}
\hline$\Delta \mathrm{Z}^{-S_{\text {Score }}}(\mathrm{t}-1)-(\mathrm{t}-2)$ & $\begin{array}{c}-0.001 \\
(-1.401)\end{array}$ & \\
\hline \multicolumn{2}{|l|}{$\Delta$ Debt Ratio (Market) $(\mathrm{t}-1)-(\mathrm{t}-2)$} & $\begin{array}{c}0.031 \\
(1.251)\end{array}$ \\
\hline$\Delta \mathrm{ROA}_{(\mathrm{t}-1)-(\mathrm{t}-2)}$ & & $\begin{array}{c}-0.022 \\
(-0.602) \\
\end{array}$ \\
\hline$\Delta \operatorname{Size}_{(\mathrm{t}-1)-(\mathrm{t}-2)}$ & $\begin{array}{c}0.007 * * \\
(2.003)\end{array}$ & $\begin{array}{c}0.007 * * \\
(2.362)\end{array}$ \\
\hline$\Delta$ Market to Book Ratio $_{(\mathrm{t}-1)-(\mathrm{t}-2)}$ & $\begin{array}{c}0.000 \\
(1.076)\end{array}$ & $\begin{array}{c}0.000 \\
(0.918)\end{array}$ \\
\hline$\Delta \mathrm{E}^{-i n d e x}{ }_{(\mathrm{t}-1)-(\mathrm{t}-2)}$ & $\begin{array}{c}0.003 \\
(0.774)\end{array}$ & $\begin{array}{c}0.002 \\
(0.473)\end{array}$ \\
\hline$\Delta$ Current Ratio $(\mathrm{t}-1)-(\mathrm{t}-2)$ & $\begin{array}{c}0.007 * * * \\
(2.618)\end{array}$ & $\begin{array}{c}0.006 * * \\
(2.260)\end{array}$ \\
\hline$\Delta$ Rank_First $_{(\mathrm{t}-1)-(\mathrm{t}-2)}$ & $\begin{array}{c}0.013 \\
(1.065) \\
\end{array}$ & $\begin{array}{c}0.013 \\
(0.297) \\
\end{array}$ \\
\hline$\Delta$ Duality $_{(\mathrm{t}-1)-(\mathrm{t}-2)}$ & $\begin{array}{c}-0.016 * * * \\
(-2.566)\end{array}$ & $\begin{array}{c}-0.016^{* *} \\
(-2.512)\end{array}$ \\
\hline$\Delta$ Male $_{(\mathrm{t}-1)-(\mathrm{t}-2)}$ & $\begin{array}{c}0.017 \\
(0.661) \\
\end{array}$ & $\begin{array}{c}0.021 \\
(0.845) \\
\end{array}$ \\
\hline Year Dummies & YES & YES \\
\hline Industry Dummies & YES & YES \\
\hline R square & $0.40 \%$ & $0.30 \%$ \\
\hline $\mathrm{n}$ & 5,731 & 5,766 \\
\hline
\end{tabular}

\subsection{This Risk-Taking of Equity-Based Compensation}

Bhagat and Bolton (2014) have showed that incentives generated by executive compensation programs led to excessive risk-taking. Although we still do not know whether stock compensation or option compensation is better, we further distinguish them by examining the risk-taking of these two kinds of compensation.

Table 10A presents the OLS regressions on the stock return volatility (we identify this as "Risk"), stock return, and stock return scaled by stock return volatility. In column (1) and (2), surprisingly, stock compensation will reduce the next-year risk very significantly. In contrast, in column (5) and (6), stock compensation will increase the return/risk significantly.

Table 10B presents the OLS regressions on the stock return volatility (we identify this as "Risk"), stock return, and stock return scaled by stock return volatility. In Table 10B, column (1) and (2), option compensation will increase the next-year risk significantly. Similarly, in column (5), option compensation will decrease the next-year return/risk significantly.

To summarize, stock compensation will reduce risk and increase return/risk significantly.On the contrary, options will increase risk and decrease return/risk significantly. This result does tell us something important. It reveals that although stocks or options are better compensation components is still ambiguous, in the view of firms' risk-taking, stocks dominate options because it could reduce risk and increase return/risk ratio. 
Table 10A. the relation between risk and stock compensation

\begin{tabular}{|c|c|c|c|c|c|c|}
\hline $\begin{array}{l}\text { Non-financial } \\
\text { institutions }\end{array}$ & Risk $_{t}$ & Risk $_{t \sim t+1}$ & Return $_{\mathrm{t}}$ & Return $_{\mathrm{t} \sim t+1}$ & $\begin{array}{l}\text { Return/ } \\
\text { Risk }_{t}\end{array}$ & $\begin{array}{l}\text { Return/ } \\
\text { Risk }_{\mathrm{t} \sim \mathrm{t}+1}\end{array}$ \\
\hline Variables & (1) & (2) & (3) & (4) & (5) & $(6)$ \\
\hline Intercept $_{\mathrm{t}-1}$ & $\begin{array}{c}0.301 * * * \\
(50.482)\end{array}$ & $\begin{array}{c}0.306^{* * *} \\
(43.878)\end{array}$ & $\begin{array}{c}0.214 * * * \\
(8.572)\end{array}$ & $\begin{array}{c}0.408 * * * \\
(14.631)\end{array}$ & $\begin{array}{l}0.245^{*} \\
(1.871) \\
\end{array}$ & $\begin{array}{c}0.903 * * * \\
(5.907)\end{array}$ \\
\hline Stock $(\%)_{\mathrm{t}-1}$ & $\begin{array}{c}-0.023 * * * \\
(-4.557) \\
\end{array}$ & $\begin{array}{c}-0.030 * * * \\
(-4.927)\end{array}$ & $\begin{array}{c}0.028 \\
(1.323) \\
\end{array}$ & $\begin{array}{c}0.101 * * * \\
(4.178)\end{array}$ & $\begin{array}{c}0.491 * * * \\
(4.332)\end{array}$ & $\begin{array}{c}0.063 * * * \\
(5.907)\end{array}$ \\
\hline Debt Ratio $_{t-1}$ & $\begin{array}{c}0.086^{* * * *} \\
(15.022) \\
\end{array}$ & $\begin{array}{c}0.040 * * * \\
(5.999)\end{array}$ & $\begin{array}{c}0.265^{* * * *} \\
(11.032)\end{array}$ & $\begin{array}{c}0.187 * * * \\
(7.093)\end{array}$ & $\begin{array}{c}0.643 * * * \\
(4.731)\end{array}$ & $\begin{array}{c}0.413 * * * \\
(2.669)\end{array}$ \\
\hline $\ln (\text { Asset })_{t-1}$ & $\begin{array}{c}-0.019 * * * \\
(-22.151) \\
\end{array}$ & $\begin{array}{c}-0.017 * * * \\
(-17.098) \\
\end{array}$ & $\begin{array}{c}-0.019 * * * \\
(-5.260)\end{array}$ & $\begin{array}{c}-0.034 * * * \\
(-8.441) \\
\end{array}$ & $\begin{array}{c}0.070 * * * \\
(3.651)\end{array}$ & $\begin{array}{c}0.073 * * * \\
(3.259)\end{array}$ \\
\hline $\begin{array}{l}\text { Market to } \\
\text { Book Ratio }_{t-1}\end{array}$ & $\begin{array}{c}-0.000 \\
(-0.545)\end{array}$ & $\begin{array}{c}0.000 \\
(0.451)\end{array}$ & $\begin{array}{c}-0.001 \\
(-1.297)\end{array}$ & $\begin{array}{c}0.001 \\
(0.791)\end{array}$ & $\begin{array}{c}-0.006 * * \\
(-2.110)\end{array}$ & $\begin{array}{c}0.000 \\
(0.128) \\
\end{array}$ \\
\hline $\begin{array}{l}\text { Year } \\
\text { Dummies }\end{array}$ & Yes & Yes & Yes & Yes & Yes & Yes \\
\hline $\begin{array}{l}\text { Industry } \\
\text { Dummies }\end{array}$ & Yes & Yes & Yes & Yes & Yes & Yes \\
\hline $\mathrm{R}$ square & $7.00 \%$ & $4.90 \%$ & $1.60 \%$ & $1.40 \%$ & 0.012 & $0.50 \%$ \\
\hline $\mathrm{n}$ & 8,182 & 6,961 & 8,182 & 6,961 & 8,143 & 6,920 \\
\hline
\end{tabular}

Statistical significance at the $10 \%, 5 \%$, and $1 \%$ level is indicated by $*, * *$, and ***, respectively. T-statistics are also presented below estimates.

Table 10B. The relation between risk and option compensation

\begin{tabular}{|c|c|c|c|c|c|c|}
\hline $\begin{array}{l}\text { Non-financial } \\
\text { institutions }\end{array}$ & Risk $_{t}$ & Risk $_{t \sim t+1}$ & Return $_{\mathrm{t}}$ & Return $_{t \sim t+1}$ & $\begin{array}{c}\text { Return/ } \\
\text { Risk }_{\mathrm{t}}\end{array}$ & $\begin{array}{l}\text { Return/ } \\
\text { Risk }_{t \sim t+1}\end{array}$ \\
\hline Variables & (1) & (2) & (3) & (4) & (5) & (6) \\
\hline Intercept $_{t-1}$ & $\begin{array}{c}0.297 * * * \\
(49.317)\end{array}$ & $\begin{array}{l}0.304 * * * \\
(43.078)\end{array}$ & $\begin{array}{c}0.214 * * * \\
(8.493)\end{array}$ & $\begin{array}{l}0.402 * * * \\
(14.291)\end{array}$ & $\begin{array}{l}0.299 * * \\
(2.259)\end{array}$ & $\begin{array}{c}0.904 * * * \\
(5.855)\end{array}$ \\
\hline Option $(\%)_{\mathrm{t}-1}$ & $\begin{array}{c}0.029 * * * \\
(5.108) \\
\end{array}$ & $\begin{array}{l}0.011 * \\
(1.807)\end{array}$ & $\begin{array}{c}0.007 \\
(0.288) \\
\end{array}$ & $\begin{array}{c}0.067 * * \\
(2.547)\end{array}$ & $\begin{array}{c}-0.272 * * \\
(-2.177) \\
\end{array}$ & $\begin{array}{c}0.008 \\
(0.054)\end{array}$ \\
\hline Debt Ratio $_{t-1}$ & $\begin{array}{c}0.089 * * * \\
(15.521)\end{array}$ & $\begin{array}{c}0.041 * * * \\
(6.240)\end{array}$ & $\begin{array}{c}0.265 * * * \\
(10.984)\end{array}$ & $\begin{array}{c}0.190 * * * \\
(7.165)\end{array}$ & $\begin{array}{c}0.619 * * * \\
(4.545)\end{array}$ & $\begin{array}{c}0.411 * * * \\
(2.650)\end{array}$ \\
\hline $\ln (\text { Asset })_{t-1}$ & $\begin{array}{l}-0.020 * * * \\
(-23.831)\end{array}$ & $\begin{array}{l}-0.018 * * * \\
(-18.354)\end{array}$ & $\begin{array}{c}-0.018 * * * \\
(-5.106)\end{array}$ & $\begin{array}{c}-0.031 * * * \\
(-7.958)\end{array}$ & $\begin{array}{c}0.088 * * * \\
(4.677)\end{array}$ & $\begin{array}{c}0.075 * * * \\
(3.404)\end{array}$ \\
\hline $\begin{array}{l}\text { Market to Book } \\
\text { Ratio }_{t-1}\end{array}$ & $\begin{array}{l}-0.000 \\
(-0.631)\end{array}$ & $\begin{array}{c}0.000 \\
(0.436)\end{array}$ & $\begin{array}{c}-0.001 \\
(-1.298)\end{array}$ & $\begin{array}{c}0.000 \\
(0.701)\end{array}$ & $\begin{array}{c}-0.005^{* *} \\
(-2.012)\end{array}$ & $\begin{array}{c}0.000 \\
(0.134)\end{array}$ \\
\hline Year Dummies & Yes & Yes & Yes & Yes & Yes & Yes \\
\hline $\begin{array}{l}\text { Industry } \\
\text { Dummies }\end{array}$ & Yes & Yes & Yes & Yes & Yes & Yes \\
\hline $\mathrm{R}$ square & $7.10 \%$ & $4.60 \%$ & $1.50 \%$ & $1.20 \%$ & $1.00 \%$ & $0.50 \%$ \\
\hline $\mathrm{n}$ & 8,182 & 6,961 & 8,182 & 6,961 & 8,143 & 6,920 \\
\hline
\end{tabular}

Statistical significance at the $10 \%, 5 \%$, and $1 \%$ level is indicated by $*$, **, and ***, respectively.

T-statistics are also presented below estimates.

\section{Conclusion}

From 2006 to 2012, stock compensation plays a more and more important role in CEO compensation, from $17.3 \%$ in 2006 to $32.2 \%$ in 2012. On the contrary, option compensation is decreasing over these 7 years, from $17.3 \%$ in 2006 and 15.2\% in 2012. This paper explores to find out the determinants of the change of CEO equity-based compensation structure.

According to the results of regressions, if a CEO is also the chairman of the board of directors, the percentage of stock compensation relative to last year will decrease. For firm 
characteristics, if the change of stock price increases positively, the CEO will be viewed as a good manager and be rewarded with more equity-based compensation, making him/her more hard-working. The change of debt ratio is negatively correlated with the percentage of stock-minus-option compensation relative to last year, representing that stock compensation is a better component for firms whose probability of non-viability risk is higher (Kadan and Swinkels, 2008). The change of size is positively correlated with both the percentage of stock or stock-minus-option compensation relative to last year in non-financial institutions. To summarize, when firms perform better, sizes are bigger, and when there is a supervision mechanism of CEOs, stock compensation will rise.

We also investigated the relation between equity-based compensation and risk-raking. Surprisingly, stock compensation will decrease stock return risk of his/her own company, but option compensation will increase stock return risk of his/her own company. Although there is no obvious conclusion about whether stocks or options are better in the past researches, in the point of risk-taking, stock compensation dominates option compensation.Our results indicate that managerial incentives matter-incentives generated by executive compensation programs are correlated with risk-taking. We recommend that executive equity-basedcompensation should mostly consist of restricted stock.

\section{References}

Andergassen, R. (2008). High powered incentives and fraudulent behavior: stock based versus stock option based compensation. Economics Letters. 101. 122-125. http://dx.doi.org/10.1016/j.econlet.2008.07.009

Barron J., \& Glen Waddell. (2003). Executive rank, pay, and project selection. Journal of Financial Economics. 67. 305-349. http://dx.doi.org/10.1016/s0304-405x(02)00254-4

Bebchuk, L., Alma Cohen, \& Allen Ferrell. (2009). Whatmatters in corporate governance. Review of Financial Studies. 22(2). 783-827. http://dx.doi.org/10.2139/ssrn.593423

Bolton, B., \& Sanjai Bhagat. (2014). Financial crisis and bank executive incentivecompensation. Journal of Corporate Finance $25 . \quad 313-341$. http://dx.doi.org/10.1016/j.jcorpfin.2014.01.002

Billet, M., David Mauer, \& Yilei Zhang. (2010). Stockholder and bondholder wealth effects of CEO incentive grants. Financial Management. 39(2). 463-487. http://dx.doi.org/10.2139/ssrn.924765

Bugeja, M., Zoltan Matolcsy, \& Helen Spiropoulos. (2012). Is there a gender gap is CEO compensation.Journal of Corporate $\quad$ Finance. $18 . \quad 849-859$. http://dx.doi.org/10.2139/ssrn.1945444

Feltham, G., \& Martin Wu. (2001). Incentive efficiency of stock versus options. Review of Accounting Studies. 6. 7-28. http://dx.doi.org/10.1023/A:1011377902967

Gaver, J., \& Kenneth Gaver. (1993). Additional evidence on the association between the investment opportunity set and corporate financing, dividend, and compensation policies. 
$\begin{array}{lllllr}\text { Journal of Accounting and } & \text { Economics. } & 16 . & \text { 160 }\end{array}$ http://dx.doi.org/10.1016/0165-4101(93)90007-3

Goergen M., \& Luc Renneboog. (2011). Managerial compensation. Journal of Corporate Finance. 17, 1068-1077. http://dx.doi.org/10.1016/s0929-1199(11)00084-8

Hall, B., \& Kevin Murphy. (2000). Optimal exercise prices for executive stock options. American Economic Review. 90. 209-214. http://dx.doi.org/10.3386/w7548

Hall, B., \& Kevin Murphy. (2002). Stock options for undiversified executives. Journal of Accounting and Economics. 33, 3-42. http://dx.doi.org/10.3386/w8052

Hayes, R., Michael Lemmon, \& Mingming Qiu. (2012). Stock options and managerial incentives for risk taking: evidence from FAS 123R. Journal of Financial Economics. 105, 174-190. http://dx.doi.org/10.1016/j.jfineco.2012.01.004

Kadan, O., \& Jeroen Swinkels. (2008). Stocks or options? Moral hazard, firm viability, and the design of compensation contracts. Review of Financial Studies. 21, 451-482. http://dx.doi.org/10.2139/ssrn.665803

Kole, S. (1997). The complexity of compensation contracts. Journal of Financial Economics. 43(1), 79-104. http://dx.doi.org/10.1016/s0304-405x(96)00888-4

Lambert, R., \& David Larcker. (2004). Stock options, restricted stock, and incentives. http://dx.doi.org/10.2139/ssrn.527822

Lin, D., Hsien-Chang Kuo, \& Lie-Huey Wang. (2013). Chief executive compensation: an empirical study of fat cat CEOs. The International Journal of Business and Finance Research. 7(2), 27-42. Available at SSRN: http://ssrn.com/abstract=2149110

Meulbroek, L. (2001). The efficiency of equity-linked compensation: understanding the full cost of awarding executive stock options. Financial Management. 30, 5-30. http://dx.doi.org/10.2139/ssrn.215530

Wu, Y. W. (2011). Optimal executive compensation: Stock options or restricted stocks.International Review of Economics and Finance. 20, 633-644. http://dx.doi.org/10.2139/ssrn.970516

Palmon, O., Sasson Bar-Yosef, Ren-Raw Chen, \& ItzhakVenezia. (2008). Optimal strike prices of stock options for effort-averse executives. Journal of Banking \& Finance. 32(2), 229-239. http://dx.doi.org/10.2139/ssrn.559922

Smith, C., \& Ross Watts. (1992). The investment opportunity set and corporate financing, dividend and compensation policies. Journal of Financial Economics. 32, 263-292. http://dx.doi.org/10.1016/0304-405x(92)90029-w

Smith, C., \& Rene Stulz. (1985). The determinants of firms' hedging policies.Journal of Financial and Quantitative Analysis. 20(4), 391-405. http://dx.doi.org/10.2307/2330757

Tang, C. H. (2012). Revisiting the incentive effects of executive stock options. Journal of 


\section{Macrothink}

Business and Economic Research

ISSN 2162-4860

2014, Vol. 4, No. 2

Banking and Finance. 36, 564-574. http://dx.doi.org/10.1016/j.jbankfin.2011.09.003

\section{Copyright Disclaimer}

Copyright for this article is retained by the author(s), with first publication rights granted to the journal.

This is an open-access article distributed under the terms and conditions of the Creative Commons Attribution license (http://creativecommons.org/licenses/by/3.0/). 